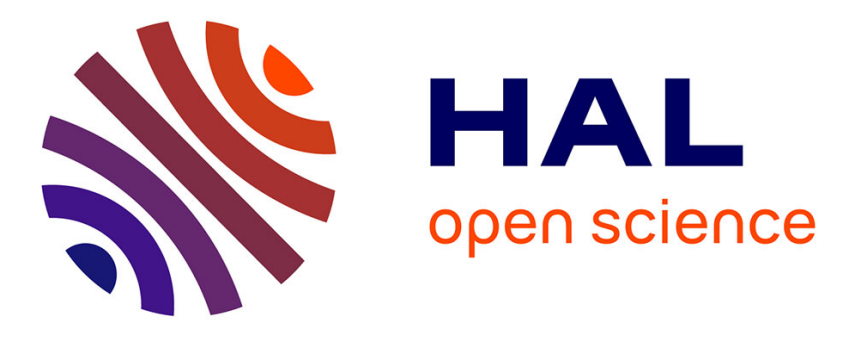

\title{
Synthesis of new calixarene phosphine oxides and their extraction properties in ionic liquids
}

Stanislav Miroshnichenko, Dariia Ternova, Isabelle Billard, Ali Ouadi, Olga Klimchuk, Vitaly Kalchenko

\section{- To cite this version:}

Stanislav Miroshnichenko, Dariia Ternova, Isabelle Billard, Ali Ouadi, Olga Klimchuk, et al.. Synthesis of new calixarene phosphine oxides and their extraction properties in ionic liquids. Phosphorus, Sulfur, and Silicon and the Related Elements, 2011, 18th International Conference on Phosphorus Chemistry (ICPC2010), 186 (4), pp.903-905. hal-02271897

\section{HAL Id: hal-02271897 https://hal.science/hal-02271897}

Submitted on 27 Aug 2019

HAL is a multi-disciplinary open access archive for the deposit and dissemination of scientific research documents, whether they are published or not. The documents may come from teaching and research institutions in France or abroad, or from public or private research centers.
L'archive ouverte pluridisciplinaire HAL, est destinée au dépôt et à la diffusion de documents scientifiques de niveau recherche, publiés ou non, émanant des établissements d'enseignement et de recherche français ou étrangers, des laboratoires publics ou privés. 
archives-ouvertes

\title{
Synthesis of new calixarene phosphine oxides and their extraction properties in ionic liquids
}

\author{
Isabelle Billard
}

\section{To cite this version:}

Isabelle Billard. Synthesis of new calixarene phosphine oxides and their extraction properties in ionic liquids. Phosphorus, Sulfur, and Silicon and the Related Elements, Taylor

Francis, 2011. hal-02271897

\section{HAL Id: hal-02271897 \\ https://hal.archives-ouvertes.fr/hal-02271897}

Submitted on 27 Aug 2019

HAL is a multi-disciplinary open access archive for the deposit and dissemination of scientific research documents, whether they are published or not. The documents may come from teaching and research institutions in France or abroad, or from public or private research centers.
L'archive ouverte pluridisciplinaire HAL, est destinée au dépôt et à la diffusion de documents scientifiques de niveau recherche, publiés ou non, émanant des établissements d'enseignement et de recherche français ou étrangers, des laboratoires publics ou privés. 


\section{SYNTHESIS OF NEW CALIXARENE-PHOSPHINE OXIDES AND THEIR EXTRACTION PROPERTIES IN IONIC LIQUIDS}

Stanislav Miroshnichenko, ${ }^{1}$ Dariia Ternova, ${ }^{1}$ Isabelle Billard, ${ }^{2}$ Ali Ouadi, ${ }^{2}$ Olga Klimchuk, ${ }^{1,2}$ and Vitaly Kalchenko ${ }^{1}$

'Institute of Organic Chemistry, NASU, Kyiv, Ukraine

${ }^{2}$ Institut Pluridisciplinaire Hubert Curien, DRS/CHNU, Strasbourg, France

Abstract New calix/4Jarenes finctionalized by $\mathrm{Alk}{ }_{2} \mathrm{P}(\mathrm{O}) \mathrm{CH}_{2}$ binding groups and $\mathrm{N}$ methylimidazolium groups at the opposite rims of the macrocyclic skeleron have been synthesized and characterized. Their extraction properties towards of $\mathrm{Eu}^{3+}$ and $\mathrm{Am}^{3+}$ in ionic liquid were investigated.

Keywords Calixarenes; ionic liquids; phosphine oxides

\section{INTRODUCTION}

The use of nuclear power has led to the accumulation of great amounts of both highand medium-level activity radioactive wastes, which require efficient methods of separation and safe disposal. The main method for the decontamination of radioactive wastes is liquid-liquid extraction of hazardous radionuclides followed by burial or transmutation. A modern approach in the design of efficient and selective extractants of radioanuclides is based on the functionalization of calixarene platform by several $\mathrm{P}=\mathrm{O}$ containing fragments, capable of cooperatively binding metal cations. ${ }^{1}$ Room temperature ionic liquids (RTIL) are promising solutions for the extraction of the radionuclides from spent nuclear fuel. ${ }^{2}$

\section{RESULTS AND DISCUSSION}

We present in this article the synthesis of a series of new cone-shaped calix[4]arenes possessing $\mathrm{CH}_{2} \mathrm{P}(\mathrm{O}) \mathrm{Alk}_{2}$ metallocomplexing groups at the macrocyclic wide and narrow rim and $\mathrm{N}$-methylimidazolium groups at the narrow rim. Extraction properties of the calixarene synthesized and dissolved in ionic liquid were investigated.

Calix[4]arenes 3-10 functionalized by four or eight $\mathrm{Alk}_{2} \mathrm{P}(\mathrm{O}) \mathrm{CH}_{2}$ binding groups have been synthesized by the Arbuzov reaction of tetrachloromethylcalix[4]arenes 1, 2 with dialkylphosphinites.

Received 29 July 2010; accepted 20 September 2010

Address correspondence to Isabelle Billard, Institut Pluridisciplinaire Hubert Curien, DRS/CHNU, 23 rue du loess, 67037, Strasbourg Cedex 2, France. E-mail: lsabelle.billard@ires.in2p3.fr and Vitaly 1. Kalchenko, Institute of Organic Chemistry Chemistry, NAS of Ukraine, 5 Murmanska str., 02660, Kyiv-94, Ukraine. E-mail: vik@ioch.kiev.ua 
2

S. MIROSHNICHENKO ET AL.

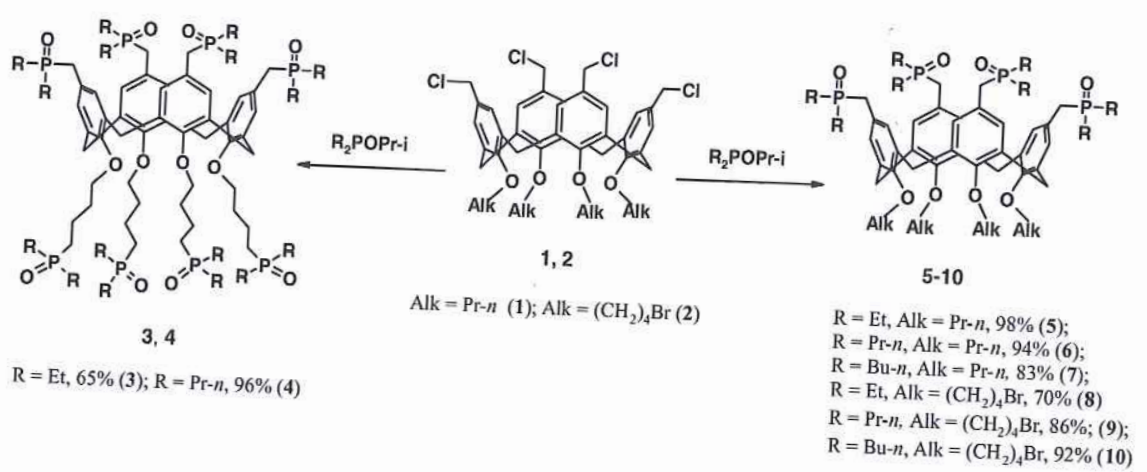

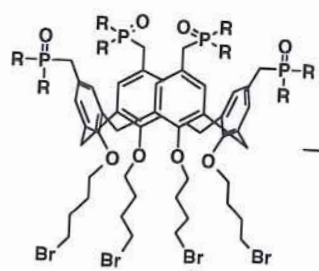

8,10

$\mathrm{R}=\mathrm{Et}(8), \mathrm{R}=\mathrm{Bu} n(10)$

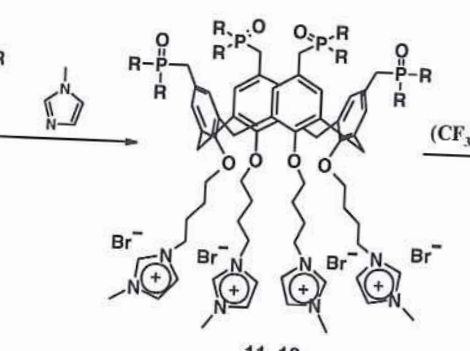

11,12

$\mathrm{R}=\mathrm{Et}, 87 \%(11) ; \mathrm{R}=\mathrm{Bu}-h, 82 \%(12)$

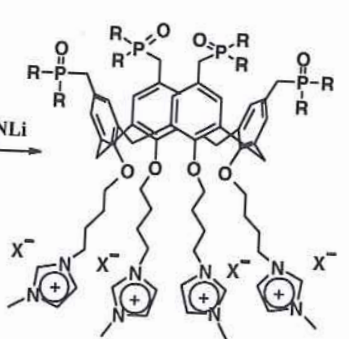

13,14

$R=E t, X=\left(C_{3} \mathrm{SO}_{2}\right)_{2} \mathrm{~N}, 94 \%(13)$; $\mathrm{R}=\mathrm{Bu}-n, \mathrm{X}=\left(\mathrm{CF}_{3} \mathrm{SO}_{2}\right) \mathrm{N}, 86 \%(14)$

Figure 1 Synthesis of calixarene phosphine oxides.

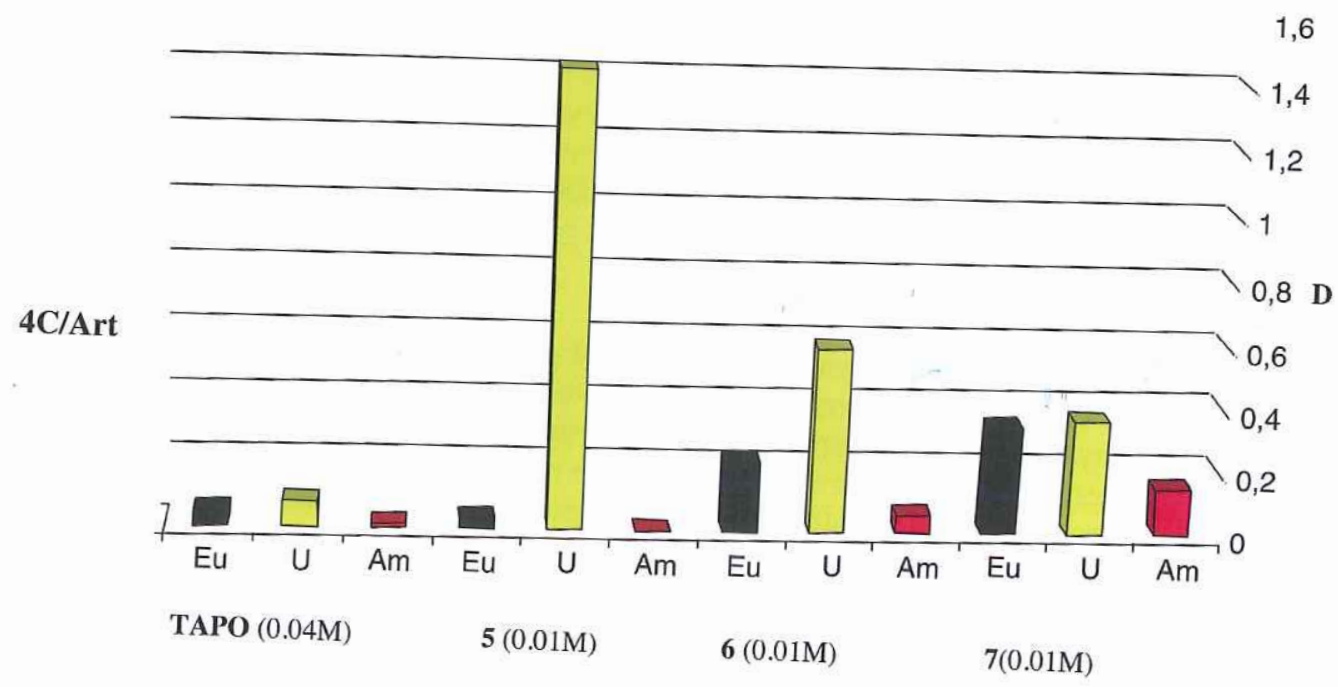

Figure 2 Extraction of $\mathrm{Eu}^{3+}, \mathrm{UO}_{2}^{2+}, \mathrm{Am}^{3+}$ by phosphine oxides from $\mathrm{HNO}_{3}(0.3 \mathrm{M})$ into $N-b u t y l-N-2$ phases; TAPO-trioctylphosphine distribution ratio of the metal cations between the ionic liquid and $\mathrm{HNO}$ 
$\operatorname{Tetra}(N$-methylimidazolium) derivatives 11,12 were prepared by the reaction of 31 bromobutoxycalixarenes 8, 10 with $\mathrm{N}$-methylimidazole. Metathetical reactions of bromides $32 \mathrm{11}, 12$ with $\mathrm{LiN}\left(\mathrm{SO}_{2} \mathrm{CF}_{3}\right)_{2}$ in DMF gave new quaternary salts $\mathbf{1 3}, 14$ (Figure 1). 2). The calixarene tetraphosphine oxides 5-7 are more efficient extractants than industrial trialkylphosphine oxides. Calixarene 5 demonstrates high selectivity in $\mathrm{UO}_{2}{ }^{2+}$ extraction.

\section{REFERENCES}

38 1. Smirnov, I.; Kara van, M.; Babain, V.; Kvasnitskiy, I.; Stoyanov, E.; Miroshnichenko, S. Radiochim. 39 Acta 2007, 95, 97-102.

40 2. Ouadi, A.; Gadenne, B.; Hesemann, P.; Moreau, J. J. E.; Billard, I.; Gaillard, C.; Mekki, S.; 41 Moutieıs, G. Chem. Eur: J. 2006, 12, 3074-3081. 